\title{
Kinetic Symbol: Falconry as Image Vehicle in the United Arab Emirates
}

\author{
Yannis Hadjinicolaou
}

1

The Desert Falcon

A bearded laughing man wearing his kandoura emerges from a fuzzy background (fig. 7.1). On his left hand, he is holding a falcon. The standing man, wearing a falconer's glove, looks toward the falcon, tracing in a proprioceptive way the bird's movement. The photograph reminds one of a ruler's image (view from below, monumental figure). And, indeed, the man in the photograph is none other than Zayed bin Sultan Al Nahayan, the first President of the United Arab Emirates, who played an immense role in the union of the Emirates in 1971. A passionate falconer, Sheikh Zayed is depicted in many photographs with birds of prey that became a sort of alter ego of the ruler:

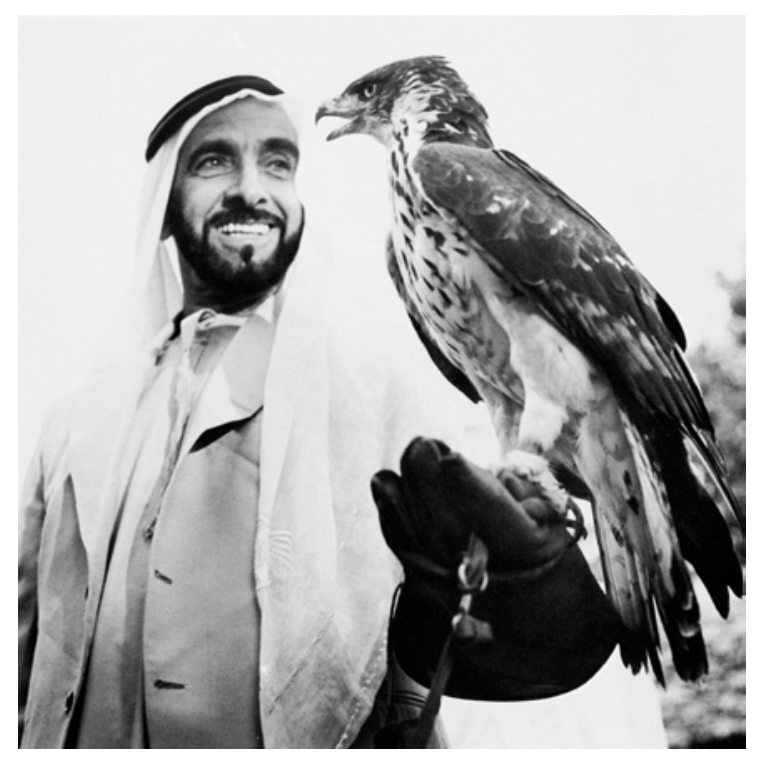

FIGURE 7.1 Zayed bin Sultan Al Nahayan with a falcon. in an early 1974 biography, he was even described as a desert falcon. ${ }^{1}$

As a dual symbol of power and heritage, falconry is a productive addition to the economic globalization of the U.A.E. ${ }^{2}$ From ancient times, falconry has explicitly cultivated a place of memory, yet it is not oriented only toward the past. On the one hundred Dirham banknote, for instance, tradition merges with technological innovation since the local saker falcon is represented looking in the direction of a modern building (fig. 7.2). The bird of prey is placed nearer to the viewer in comparison to the architectural landmark, which enhances its identification by the Emirati beholders as their national symbol. Modern buildings, such as the one on the one hundred Dirham note, were already

1 Claud Morris, The Desert Falcon: The Story of H.H. Sheikh Zayed Bin Sultan al Nahiyan President of the United Arab Emirates (London: Morris International, 1974).

2 See for instance Ahmed K.A. Al Mansoori, The Distinctive Arab Heritage. A Study of Society, Culture and Sport in the United Arab Emirates (Abu Dhabi: Emirates Heritage Club, 2004); Ken Riddle, The Art of Falconry from Arabia Westward. Training and Conditioning Captive Raised Falcons (Abu Dhabi: Motivate Publishing, 2009); Katrin Bromber and Birgit Krawietz, "The United Arab Emirates, Qatar, and Bahrain as a Modern Sport Hub," in Sport Across Asia: Politics, Cultures, and Identities, ed. Katrin Bromber, Birgit Krawietz, and Joseph Maguire (New York: Routledge 2012), 189-211; Sarina Wakefield, "Falconry as Heritage in the United Arab Emirates," World Archaeology 44, no. 2 (2012): 280-9o; Birgit Krawietz, "Falconry as a Cultural Icon of the Arab Gulf Region," in Under Construction: Logics of Urbanism in the Gulf Region, ed. Steffen Wippel, Katrin Bromber, Christian Steiner, and Birgit Krawietz (Farnham: Ashgate, 2014), 131-46. 


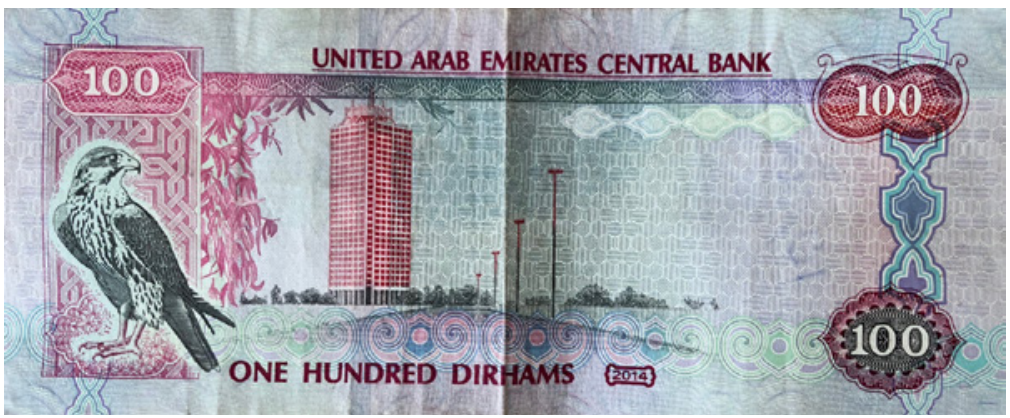

FIGURE 7.2

A one-hundred-dirham banknote with the local saker falcon, the national symbol of the U.A.E. emerging in the early 1980 s. This visual medium points to the modernity of the country, on the one hand, and to the popularity of the traditional practice of falconry, on the other. In this example, the building is the well-known World Trade Center in Dubai, a symbol of the economic boom of the Emirates and of the astonishing prosperity of the country. ${ }^{3}$ The falcon is not only a symbol of the past but also of the present, although it currently bears different connotations than in the pre-oil era.

My focus in this chapter is on the iconic power of images of falconry in the U.A.E. I discuss here falconry as a deeply visual phenomenon, an issue yet to be investigated by current scholarship. In the case of the U.A.E., the imagery of falconry, both in its compositional and technical sense, derives from an Occidental medial point of view. I refer here less to the practice of falconry itself, which was imported from the East to the West, and more to its visual representation. ${ }^{4}$ The East-West interactions are not one way communications but, as I argue here, interfaces of constant and ongoing dialogue. Because the falconry imagery in the U.A.E. and in the Gulf in general has its origins in Western pictorial practices, I will start by taking a brief look at those images and their Occidental pictoriality in order to highlight their similar use of falconry as a symbol for power and ruling. I will then

3 With thanks to Melissa Gronlund for the identification of the building.

4 This is one of the goals of my monograph, The Visual Power of Medieval Falconry, forthcoming from Reaktion Books (2021/2022). turn to the symbolic value of the falcon in the U.A.E. and discuss its role in the process of Emirati identity formation. Finally, I will introduce Aby Warburg notion of "image vehicle," an image that does not simply illustrate a practice but constructs it in a certain way, as a bridge to the discussion of the falcon's iconic life and afterlife in the Arabian Peninsula today.

\section{2}

\section{The Power of Images}

Images do not simply illustrate linguistic meanings. They are complex entities that help us think about and affect our perception of the world. Falconry images, in particular, have specific aesthetic qualities while also representing sometimes conflicting views and ideas. These issues are often implicit since they involve non-verbal communication; however, the arguments these images make must be put into words, an attempt that has its own challenges as it involves the verbalization of a non-linguistic medium.

After the introduction of falconry as a practice in Italy and Germany by Frederick II of Hohenstaufen (d.1250), falconry images had a huge impact on the Western world and helped create a global imagery heavily influenced by Arabic sources. ${ }^{5}$ This pictoriality of falconry in Europe had a significant impact on the Arab world subsequently, functioning as a

\footnotetext{
5 See Yannis Hadjinicolaou, “'Ich zog mir einen Falken.' Das ikonische Nachleben der Falknerei” ["I trained a falcon." The visual afterlife of falconry], Pegasus. Berliner Beiträge zum Nachleben der Antike, 18/19 (2018): 188.
} 
kind of iconic feedback loop. In other words, Frederick II's promotion of falconry contributed, among other things, to the formation of an "Arab heritage": Frederick took up Arab falconry techniques that appeared in Western images of falconry depicting a "genuine Arab" practice, images that were later introduced in the Gulf area.

Historically, images of falcons have often been associated with the art of war, bearing connotations of valiance and bravery. In a sixteenth-century emblem by Joachim Camerarius, for instance, one can see an open landscape with a village in the background and a falcon falling upon a heron (fig. $7 \cdot 3)$. The struggle between the two is a common emblematic theme in Western iconography and, as such, it has a meaning that goes beyond the visual one because emblems are always connected with texts. In this case, the image refers to the art of war because the accompanying text reads: "The outcome of the fight is uncertain." ${ }^{\prime 6}$ The bald branch in the foreground, growing out of a tree stump, points to the fight, leaving open the possibility of decay or rebirth and underlining the uncertain outcome of the confrontation. A miniature from the Museum in Aurangabad (Maharrashtra, India) similarly comments on this fact: it shows a falconry scene above, where a falcon triumphs over a heron, and a battle below, where elephant riders kill a warrior on a horse (fig. 7.4). As indicated by such images, both Western and Eastern cultures use a similar iconography of falconry as a paradigm for battle.

When analyzing the above-mentioned images, it is obvious not only that falconry was perceived at the time as closely related to the idea of war but also that it had broader political implications. The image of the falcon as a war and political symbol is found, for example, in a painting of the Flemish court artist David Teniers the Younger (fig. 7.5).

Arthur Schenkel and Albrecht Schöne, Emblemata. Handbuch zur Sinnbildkunst des XVI. und XVII. Jahrhunderts [Emblemata. Handbook of symbols of the sixteenth and seventeenth centuries] (Stuttgart: Metzler, 1967), 785 .

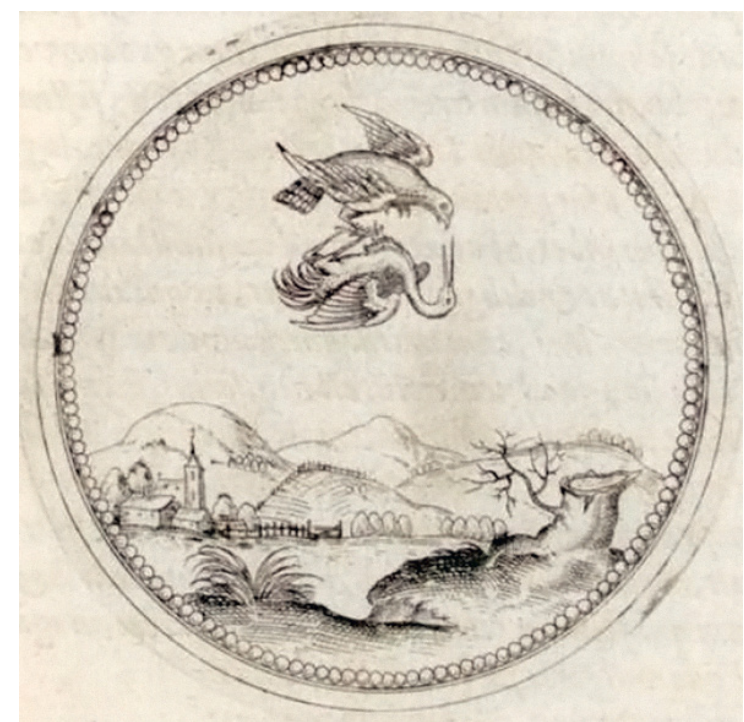

FIGURE 7.3 The Outcome of the Fight Is Uncertain (Exitus in dubio est). Emblem, Joachim Camerarius, Symbolorum \& Emblematicum, III No. 32, Nurenberg 1598.

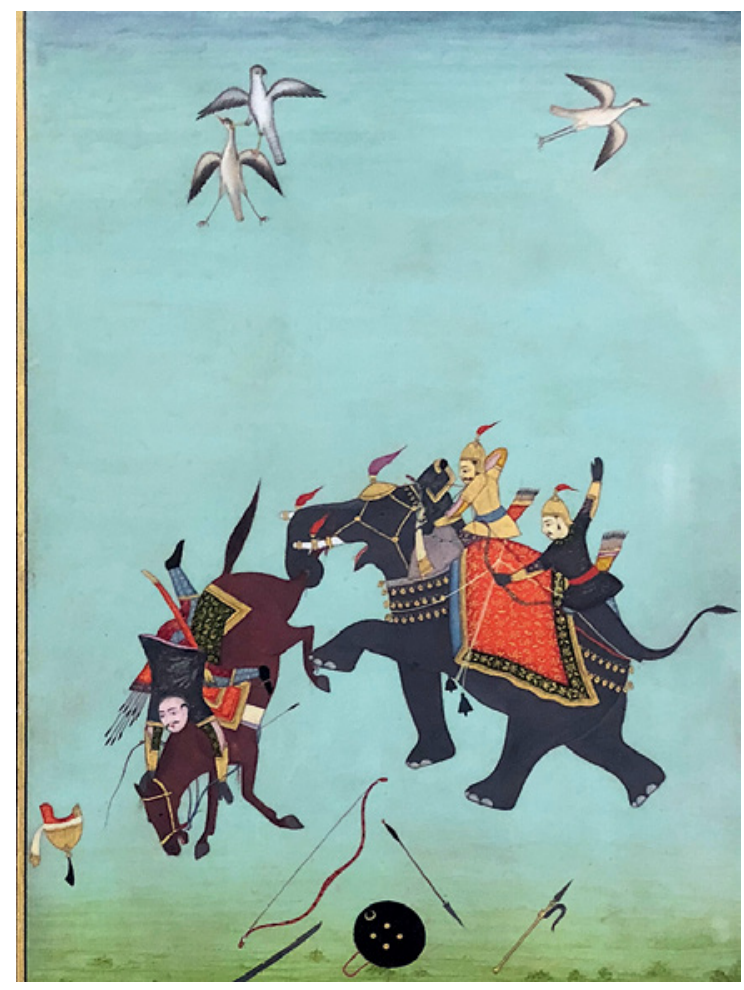

FIGURE 7.4 [Unknown artist from Maratha], Battle Scene. Miniature, 18th century. 


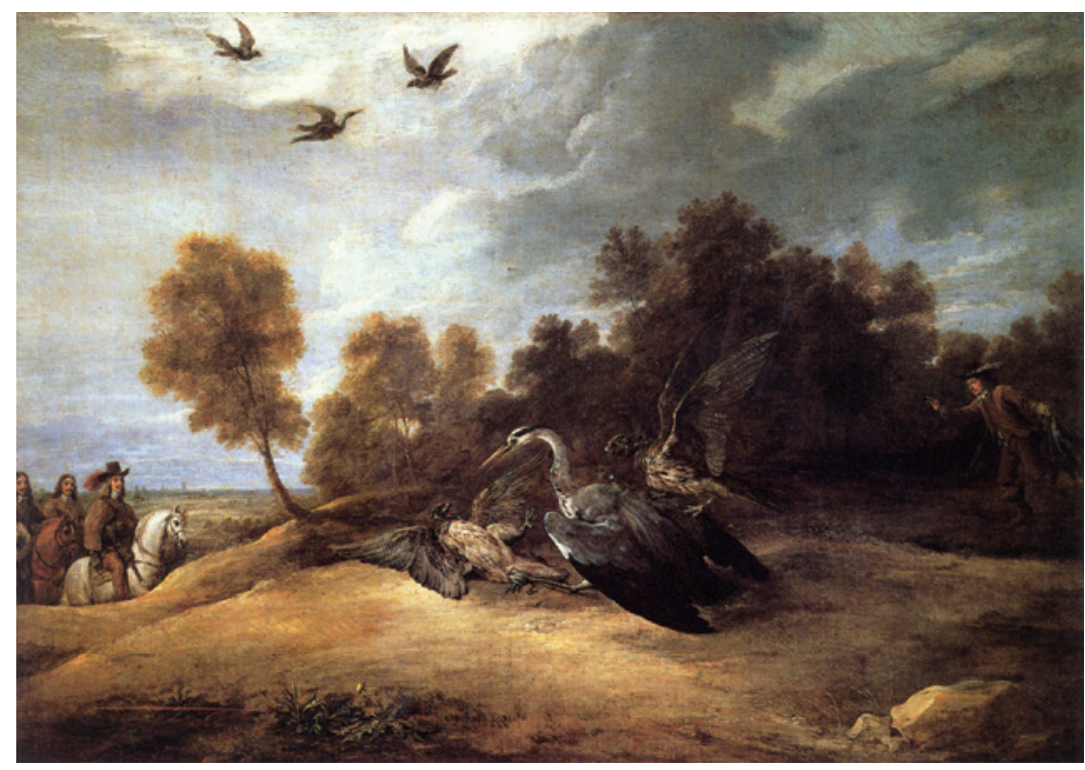

FIGURE 7.5

David Teniers the Younger, Heron Hunt with Archduke Leopold

William. Oil on canvas, ca. 1654.
Teniers painted his benefactor and defender of the southern provinces of the Netherlands in the Thirty Years' War, Count Leopold Wilhelm, mounted on a horse. He follows here a painting tradition established by Pieter Aertsen and Joachim Beuckelaer, who placed religious scenes in the background and brought to the foreground genre and still-life motives, such as markets or butcher shops. ${ }^{7} \mathrm{Te}$ niers merges here historic and genre painting with still-life painting into an original pictorial composition. The image is very different from common royal portraiture. In this work, the heron is attacked from both sides by falcons. Up in the sky, a similar confrontation takes place, suggesting the war between the southern provinces of the Netherlands, on the one hand, and France and the northern provinces of the Netherlands, on the other. This emblematic constellation leaves the outcome open although the painter and Leopold Wilhelm are clearly on the side of the southern Netherlands. According to some scholars, the falcons symbolize here France and the northern Dutch provinces while the herons symbolize the southern Dutch

For details, see Victor Stoichita, The Self-Aware Image. An Insight into Early Modern Meta-Painting (Turnhout: Brepols, 2015). provinces. ${ }^{8}$ However, the falcons are encircled by Leopold Wilhelm's hunting party, a detail that may suggest a different interpretation of the scene. In this case, the falcons may symbolize the southern Dutch provinces fighting against their enemies in general. Teniers purposefully placed his signature on a stone on the right-hand side of the painting, where a falconer with a lure in his hand is running toward the birds of prey, to suggest his role as an observer and commentator on the political implications of the scene. In other words, the artist serves here the sovereign without neglecting his own artisanal sovereignity, as underlined by the placement of his signature on a political allegory.

\section{$3 \quad$ Origins of Falconry}

The idea of falconry as a ruler's exercise and its pictorial afterlife have a global dimension, as testified by images deriving from or circulating throughout the Arab world, Europe, and Asia. ${ }^{9}$ It is common knowledge that Frederick II hired

Hans Vlieghe, David Teniers the Younger (1610-169o). A Biography (Turnhout: Brepols, 2011), 33.

9 For a compelling argument about the transnational circulation of ideas and things, see Michael Edwardes, 
falconers from different parts of the world to learn this art. ${ }^{10}$ This fact not only explains how various cultural practices shape images of falconry associated with a ruler but also provides very concrete proof of Frederick II's universalism. The iconic afterlife of falconry is a cross-cultural phenomenon that has taken new shapes and meanings throughout the centuries.

As Hans Epstein and Kurt Lindner have shown, falconry was considered as a barbaric practice in the Occident. ${ }^{11}$ It was cultivated in the Asian and African-Roman provinces and, later, in the Byzantine Empire, wherefrom it was subsequently brought to Europe in the 6th century A.D. ${ }^{12}$ Aristotle mentions falconry in his Historia Animalium (History of Animals), where he indicates that this practice was common in Kedripolis (Thrace). ${ }^{13}$ Similarly, the Near and Middle East (according to Xenophon, Persia was the main place for raising birds of prey), ${ }^{14}$ China (during the Han Dynasty),

East-West Passage: The Travel of Ideas, Arts and Inventions between Asia and the Western World (London: Cassell, 1971). John Cummins, The Hound and the Dog. The Art of Medieval Hunting (London: Weidenfeld and Nicholson 1988), 219.

Kurt Lindner, Beiträge zu Vogelfang und Falknerei im Altertum [Contributions to bird trapping and falconry in ancient times] (Berlin: De Gruyter, 1973). I return to this idea when discussing Aby Warburg's notion of "image vehicle" below.

Hans Epstein, "The Origin and Earliest History of Falconry," Isis 34, no. 6 (1943): 497-509; Lindner, Beiträge $z u$ Vogelfang, 9o. Augustine of Hippo indicates that Vandals in North Africa were keeping birds of prey and hunting dogs. For details, see Robert Seidenader, Kulturgeschichte der Falknerei mit besonderer Berücksichtigung von Bayern. Von Augustinus bis Kurfürst Maximilian I [Cultural history of falconry with special consideration of Bavaria. From Augustinus to Elector Maximilian I] (Munich: Private Printing, 2007), 1:29.

13 Aristotle, Historia animalium IX, 36, 62ob. Loeb Classical Library, www.loebclassics.com/view/aristotlehistory_animals/1965/pb_LCL437.3.xml (accessed November 5, 2018); Lindner, Beiträge zu Vogelfang, 112.

14 Henry Maguire, "'Signs and Symbols of Your Always Victorious Reign.' The Political Ideology and Meaning
India (around 400 B.c.), ${ }^{15}$ and Mongolia (since prehistoric times) were, among other places, known areas for practicing falconry. Frederick II "imported" this cultural practice from the Arab world, where it started to unfold its iconic status. ${ }^{16}$ Thus, from its very beginning, falconry emerged more or less simultaneously in widely disparate places, such as Scandinavia, Central

of Falconry in Byzantium," in Images of the Byzantine World: Visions, Messages and Meanings: Studies Presented to Leslie Brubaker, ed. Angeliki Lymberopoulou (Farnham: Ashgate, 2011), 144. See also Epstein, "The Origin and Earliest History of Falconry," 501.

15 Lindner, Beiträge zu Vogelfang, 117. See also Thomas T. Allsen, The Royal Hunt in Eurasian History (Philadelphia: University of Pennsylvania Press, 2006).

16 Lisa Anna Medrow, "Falkenjagd in Arabien im 8.-13. Jahrhundert" [Hawk hunting in Arabia in the 8th-13th centuries], in Kaiser Friedrich II. (1194-1250). Welt und Kultur des Mittelmeerraums [Emperor Frederick II (1194-1250). World and culture of the Mediterranean], ed. Mamoun Fansa and Karen Ermete (Mainz: Philipp von Zabern 2007), 15; Javier Ceballos, Falconry. Celebrating a Living Heritage (Dubai: Motivate Publishing, 2009), 146-47. It is known, for instance, that Frederic II imported from the Arab world the hood: "The falcon's hood is a discovery of oriental peoples, the Arabs having, so far as we know, first introduced it into active practice. We ourselves, when we sailed across the seas, saw it used by them and made a study of their manner of manipulating this head covering. The Arabian chiefs not only presented us with many kinds of falcons but sent with them falconers expert in the use of the hood. In addition to these sources of knowledge from the time when we first decided to write a book, a complete treatise on falconry, we have imported partly form Arabia, partly from other countries, both birds and men skilled in the art, from whom we have acquired a knowledge of all their accomplishments." See Frederick II of Hohenstaufen, The Art of Falconry; Being the De Arte Venandi cum Avibus of Frederick II of Hohenstaufen, trans. and ed. Casey A. Wood and F. Marjorie Fyfe (Stanford: Stanford University Press, 1943), 205. This does not mean however that there was no falconry in Europe before Frederick II. Here I rather refer to certain techniques also manifested in images. 


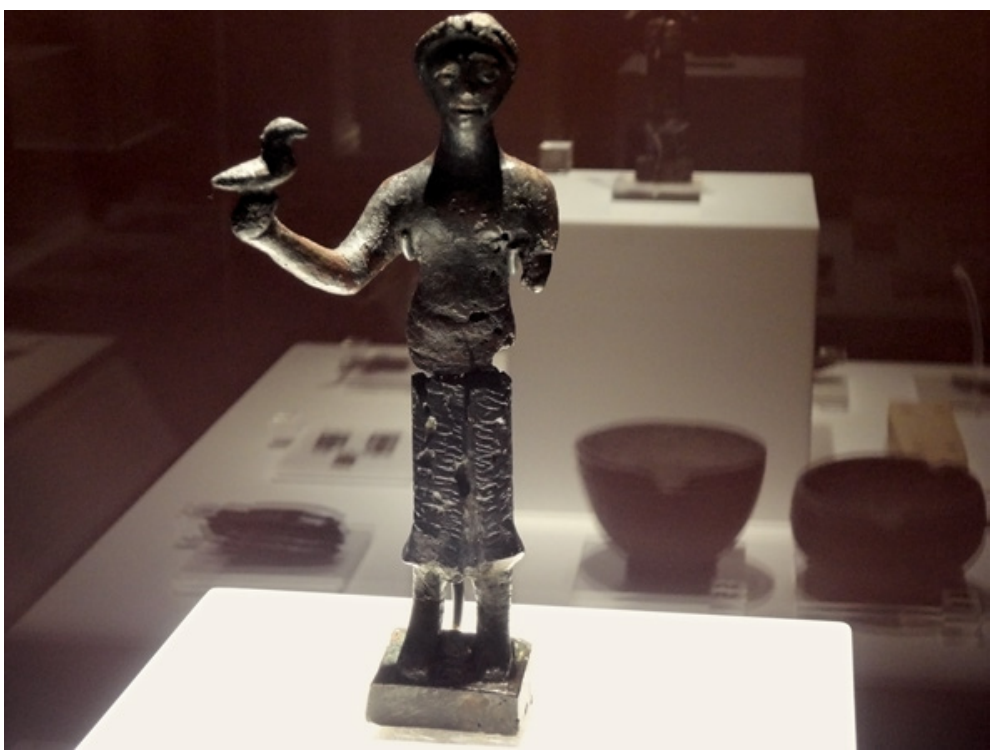

\section{FIGURE 7.6}

A male figure holding a bird of prey dated between the third century B.C. and the second century A.D. Copper alloy.

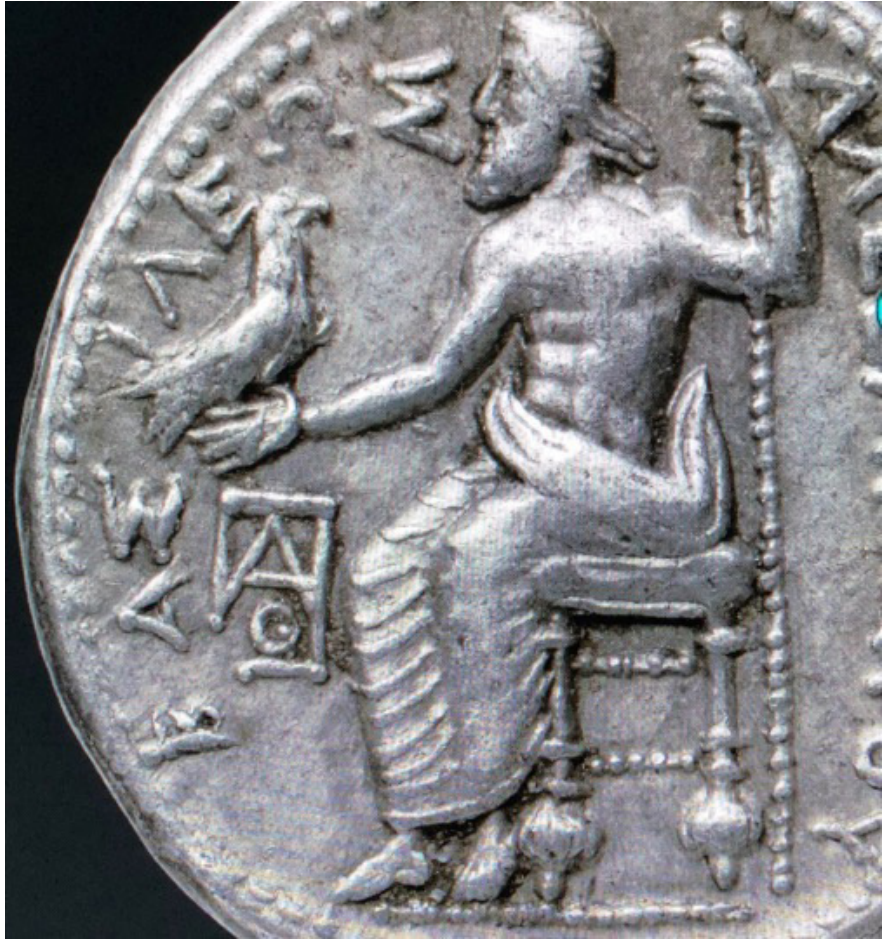

FIGURE 7.7

Tetradrachm of Alexander the Great. Reverse Zeus with eagle with the Greek inscription "King Alexander," the fourth century B.c.
Asia, and the Arabian Peninsula. ${ }^{17}$ When dealing with falconry images, therefore, one should

17 See the English summary to Raptor and HumanFalconry and Bird Symbolism throughout the Millennia on a Global Scale, ed. Karl-Heinz Gersmann and Oliver Grimm (Kiel: Wachholtz, 2018), 18-25. consider a broader, global antiquity rather than a narrow, European one.

Even if images of birds of prey were not widespread in the pre-Islamic period, they can still be found in the art of the time. For instance, a male figure holding a bird of prey dated between the third century B.C. and the second century A.D. and 
displayed at the Archaeological Museum in Sharjah (fig. 7.6) shows a figurative coupling of a human and a bird in this region. Even if this representation may have been a Western import similar to the famous coins depicting Zeus holding an eagle (fig. 7.7), it is, still, an important example as it indicates a visual engagement with this subject. Such images have certainly played an important role in the development of visual representations of a human being (or ruler) holding a bird of prey, which is one of the most common iconographic renditions of falconry in this region.

\section{$4 \quad$ Falconry in the Emirates}

As argued above, falconry was often represented in European images and texts as an explicitly political activity. This is also obvious in the programmatic book, Falconry as a Sport-Our Arab Heritage, which was published for the First Falconry Festival in 1976, five years after the founding of the U.A.E. (fig. 7.8). ${ }^{18}$ Celebrating falconry was a way for the young state to create an identifying figure and make it known internationally through the organization of a local event. Thus, the festival created visibility for the new state after its declaration of independence from the British protectorate. The falcon was an ideal identifying image not only inside but also outside the borders of the newly-established state. The current perception of the U.A.E. outside the country is based, among other things like its megamalls or oil drills, on this particular symbol. The falcon has now become the official symbol of the Emirates. ${ }^{19}$

The insistence on falconry as a sport should not take, however, from another central function

18 Zaid Bin Sultan Al Nahayan, Falconry as a Sport-Our Arab Heritage (Abu Dhabi: Westerham Press, 1976).

19 It is not a coincidence that UNESCO's declaration of falconry as intangible heritage was heavily based on the decisive role played by the U.A.E. For details, see "Falconry, aLiving HumanHeritage," UNE scoIntangible Cultural Heritage, https://ich.unesco.org/en/RL/falconrya-living-human-heritage-01209(accessedJuly15, 2018).

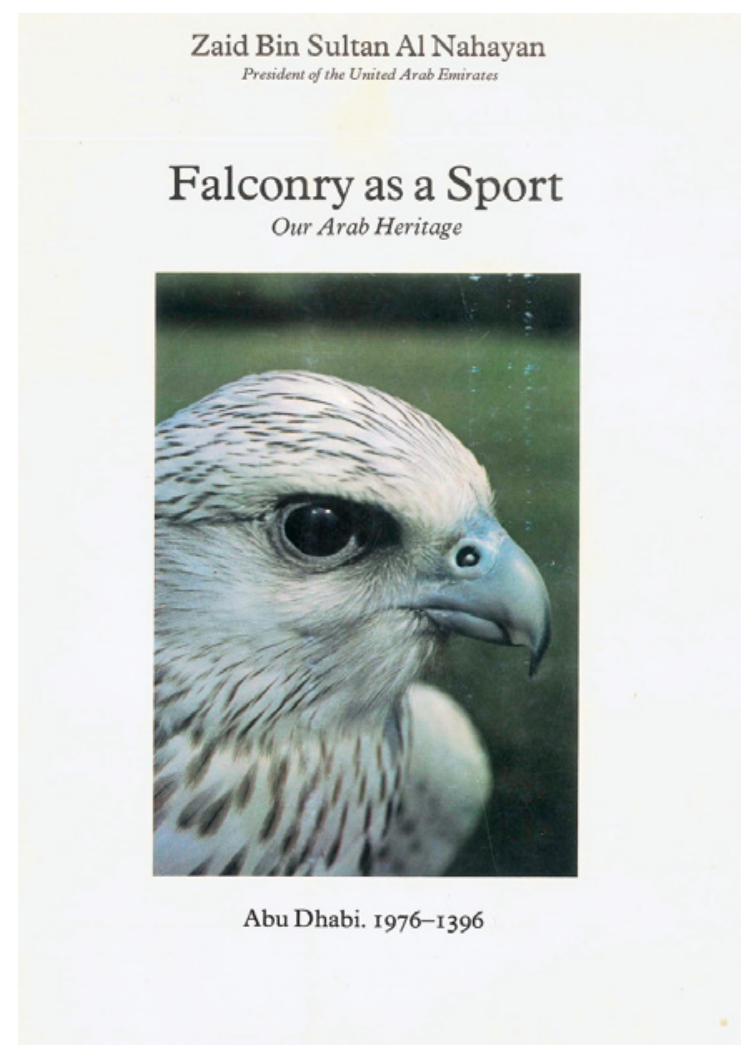

FIGURE 7.8 Cover image, Zayed bin Sultan Al Nahayan, Falconry as a Sport-Our Arab Heritage.

of the falcon, namely that of hunting. The latter activity ensured the daily nutrition of the local Bedouin population, who elevated falconry to an art form. Sheikh Zayed's Falconry as a Sport reminds one of Frederick II's De Arte Venandi Cum Avibus (The Art of Flying with Birds). ${ }^{20}$ Frederick's book is heavily based on Arabic knowledge

20 An essential bibliography on this topic includes: Baudouin van den Abeele, La Fauconnerie dans les lettres françaises du XIIe au XIVe siècle [Falconry in French literature from the twelfth to the fourteenth century] (Leuven: Presses Universitaires, 1990); Johannes Fried, Kaiser Friedrich II. als Jäger oder Ein zweites Falkenbuch Kaiser Friedrichs II.? [Emperor Frederick II as a hunter or a second falcon book of Emperor Frederick II?] (Goettingen: Vandenhoeck \& Ruprecht, 1996); Daniela Boccassini, Il volo della mente. Falconeria e sofia nel mondo mediterraneo: Islam, Federico II, Dante [The flight of the mind. Falconry and wisdom in the Mediterranean world: Islam, Federico II, Dante] 
and practices that he had became familiar with during his expeditions in the Holy Land and through direct contact with Arab falconers whom he employed in his court. Just like Frederick II, in Falconry as a Sport-Our Arab Heritage, Sheikh Zayed refers explicitly to the similarity between hunting and handling affairs of state:

"Despite the heavy demands of my task in building up our young state I resolved to meet this request [of writing this book] ... Some wise kings and rulers have been criticized for their attachment to the hunt on the grounds that it distracts them from affairs of State. They reply that they derive great benefits from their indulgence in it. Not least of

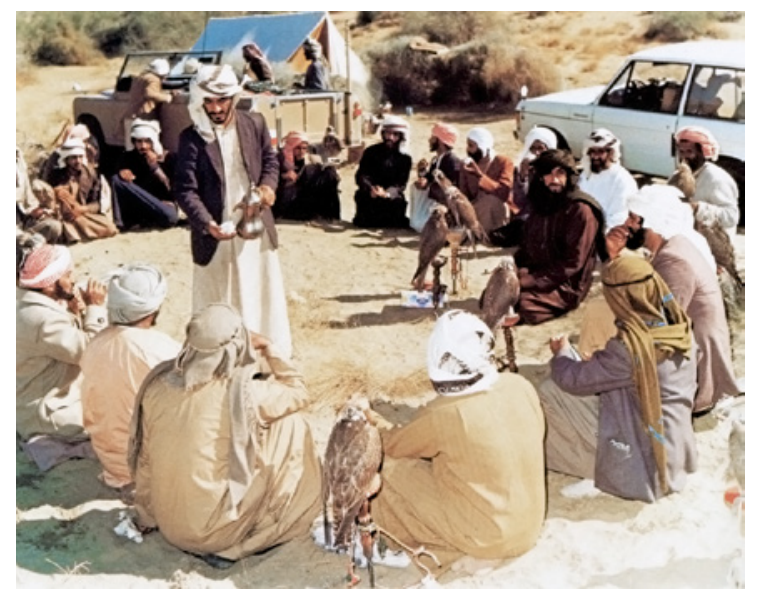

FIGURE 7.9 Zayed bin Sultan Al Nahayan during a falconry expedition. Reprinted from Zayed bin Sultan Al Nahayan, Falconry as a Sport-Our Arab Heritage, p. 76.

(Ravenna: Longo, 2003); Michael Menzel, "Die Jagd als Naturkunst. Zum Falkenbuch Kaiser Friedrichs II" [Hunting as a nature art. To the falcon book Emperor Friedrich II], in Natur im Mittelalter, ed. Peter Dilg (Berlin: Akademie Verlag, 2003), 342-59; Fansa and Ermete, eds., Kaiser Friedrich II; Mamoun Fansa and Carsten Ritzau, eds., Von der Kunst mit Vögeln zu jagen. Das Falkenbuch Friedrichs II. Kulturgeschichte und Ornithologie [From the art of hunting with birds. The falcon book of Frederick II. Cultural history and ornithology] (Mainz: Philipp von Zabern 2007); Stefan Georges, Das zweite Falkenbuch Kaiser Friedrichs II, Quellen, Entstehung, Überlieferung und Rezeption des these is the knowledge acquired about the state of the land, its progress, development and prosperity, or otherwise. If they find shortcomings or things which displease them they can set them right. At the same time, under-privileged citizens have an opportunity to make their problems known to the king."21

The role of companionship in strengthening the body of the state during falconry expeditions is also highlighted by a 1970 photograph featuring Sheikh Zayed (fig. 7.9). A group of men are drinking coffee in the desert, gathered in a circle. In the foreground, Zayed is shown surrounded by falcons and looking at his companions. This image reminds the viewers that the origins of the Emirates lie in the desert. Falconry reinforces a sense of physical and spiritual community, regardless of the social status of the participants. This aspect is emphasized by Sheikh Zayed himself:

"Another very important factor which led me to prefer falconry was its more sociable aspect. A hunting expedition with falcons brings together a group of men, never more than sixty and never less than ten. It may last for a week or more. The group may include a king, a governor, a prince or a

Moamin [The second book of falconry of the Emperor Frederick II, sources, origin, transmission and reception of Moamin] (Berlin: Akademie Verlag, 2008); and Johannes Fried and Gundula Grebnerand, eds., Kulturtransfer und Hofgesellschaft im Mittelalter. Wissenskultur am sizilianischen und kastilischen Hof im 13. Jahrhundert [Cultural transfer and court society in the Middle Ages. Knowledge culture at the Sicilian and Castilian court in the 13th century] (Berlin: Akademie Verlag, 2008).

21 Al Nahayan, Falconry as a Sport, 8 and 16, respectively. A long iconographic tradition (systematically speaking since the early Middle Ages) shows that ruler and falcon have often been associated with each other. The Book of Saint Albans (1486) is a famous example: it employs a taxonomy of birds of prey corresponding to different positions in the court. The king, for instance, is associated with a gyrfalcon. For more details, see Helen Macdonald, Falcon (London: Reaktion Books, 2006), $5^{2-53 .}$ 
prominent merchant or, again, just an ordinary man who has a house and a family to support, but a love of sport, friendship and a desire for the chase brings them all together ... Each one feels a sense of release and well-being in both body and soul ... [A] hunting trip provides a good opportunity to assess men's strength or weakness of character irrespective of the chance it offers the hunter in the way of physical and spiritual exercise and unforgettable comradeship." 22

This statement reminds again of Frederick II. ${ }^{23}$ Indeed, Sheikh Zayed positions himself in this heritage and it is not by chance that he knew Frederick's book by heart. ${ }^{24}$ A passage from Frederick's Art of Falconry opens similar perspectives: "We have studied with the greatest detail all that relates to falconry, exercising both mind and body so that we might be qualified to interpret the fruits of knowledge."25 Thus, personal practice and communal experience are of central importance for the two rulers. The famous image of Frederick II with his falcon displayed on the second page of the Manfredi Manuscript (fig. 7.10) finds an iconic equivalent in a painting depicting Zayed with his two falcons and a cup of coffee in his hand (fig. 7.11). ${ }^{26}$ Both images make it clear that ruler, power, and falconry are interrelated. It is not a coincidence that a picture of Zayed with three falcons hangs in

22 Al Nahayan, Falconry as a Sport, 8-9.

23 Frederick II, The Art of Falconry, 3.

24 For details, see Hadjinicolaou, "Ich zog mir einen Falken.' Das ikonische Nachleben der Falknerei," 165-68.

Frederick II, The Art of Falconry, 3-4. See also, Robin S. Oggins, The Kings and Their Hawks. Falconry in Medieval England (New Haven, CT: Yale University Press, 2004), 5 .

26 Carl Arnold Willemsen, ed., Das Falkenbuch Kaiser Friedrich II. Nach der Prachthandschrift in der Vatikanischen Bibliothek [The falcon book of Emperor Frederick II. After the manuscript in the Vatican library] (Dortmund: Harenberg 1980), 2; Dorothea Walz and Carl Arnold Willemsen, eds., Das Falkenbuch Friedrichs II [The falcon book of Frederick II] (Graz: Akademische Druck und Verlagsanstalt, 200o).

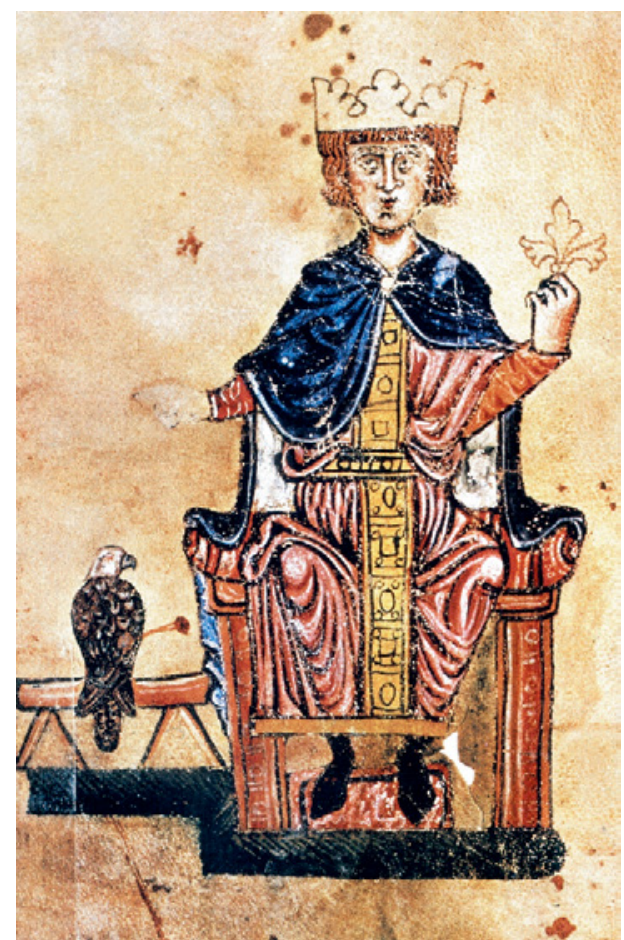

FIgure 7.10 Friedrich II, De Arte Venandi Cum Avibus. Folio lv, Manfredi Manuscript, 1258-1266.

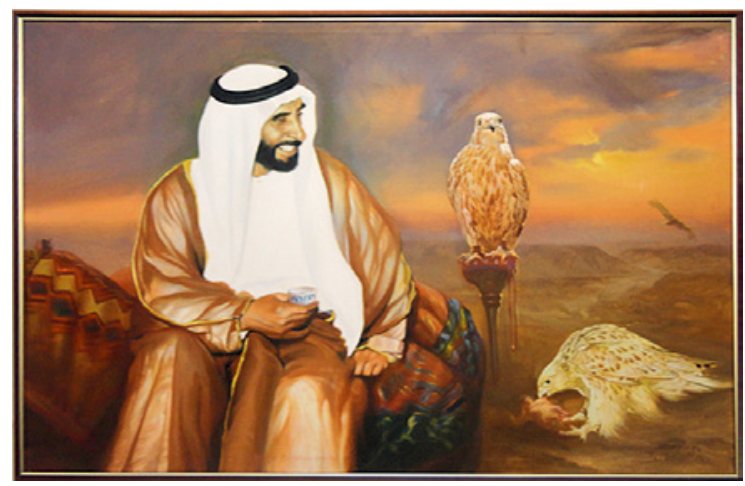

FIGURE 7.11 [Unidentified Painter], Zayed bin Sultan Al Nahayan with falcons in the desert, ca. 1990. Oil on canvas.

the majlis, or the audience room, of his palace in Al Ain, which, according to the Bedouin tradition, is reserved for discussions of state matters. The painting illuminates the falcons' role in this specific context: they fly free and are untamed, they are at the benevolence of the ruler (who feeds them when they complete their task), and they stay on their perch forming a unity with the ruler. The idea formulated in Oneirocriticon, the dream 
interpretation treatise of the scholar Achmet of Basra (653/4-728/9), that "the hawk and the falcon signify a position of power second to the king," is eloquently illuminated by this picture. ${ }^{27}$ It is also significant that the artist's signature and the date of the painting (i.e., 1999) are placed next to the falcon, which is rewarded with meat, a clear hint to the painter working under the patronage of $\mathrm{Za}$ yed's court. ${ }^{28}$

Furthermore, Zayed's idea of a communal experience during falconry expeditions seems to echo Frederick II's notion of falconry as a social leveler:

"The pursuit of falconry enables nobles and rulers worried by the cares of state to find relief in the pleasures of the hunt. The poor, as well as the less noble, may earn some of the necessities of life; and both classes will find in bird life attractive manifestations of the processes of nature." 29

Both sovereigns share the idea that falconry, as cura publica (benefit of the state), is a practice that combines state action, hunting, sport, and art. Therefore, one can argue that not Frederick's falcon practices are of interest to Zayed but his consecrating of the image of the falconer-sovereign, and of a Western visual vocabulary in general, through the miniatures in De Arte Venandi Cum Avibus. Zayed does not explicitly mention Frederick because, in

27 The Oneirocriticon of Achmet: A Medieval Greek and Arabic Treatise on the Interpretation of Dreams, trans. and ed. Stevern M. Oberhelman (Lubbock: Texas Tech University Press, 1991), 239. Achmet, who claims to be the dream interpreter of Mamun, the caliph of Babylon, explains that the treatise "was written to provide his master with a convenient ... compendium of dreamsymbols, with their various interpretative meanings, so that his master could prognosticate future events" (11). See also Maguire, "Signs and Symbols," 141.

28 For the social history of the European court artist, see Martin Warnke's seminal book, Hofkünslter. Zur Vorgeschichte des modernen Künstlers [The court artist. On the ancestry of the modern artist] (Cologne: Dumont, 1985). and Their Hawks, 127.

his eyes, the latter draws inspiration from falconry practices that Zayed considers as genuinely Arabic. ${ }^{30}$ In this sense, unlike Frederick, who transfers this knowledge through these images, Zayed does not need an intermediary because falconry is part of an uninterupted Arab heritage.

Knowing how to handle a falcon can be seen as analogous to knowing how to rule the state. ${ }^{31}$ The falcon is never fully tamed and can be lost, which can frustrate the falconer, even if this problem is less acute nowadays due to new technological developments. Similarly to the falconer, the ruler must learn early on how to approach an unexpected situation and one of the pedagogical tools used to this effect is falconry itself. For instance, a young Maximilian I, later the Holy Roman Emperor (1508-1519), is depicted in a sixteenth-century print by Hans Burgmair removing the hood of a falcon, thus demonstrating his expertise in the art of falconry, while in the background the hunting game has already begun (fig. 7.12). Learning how to handle a falcon is a complex and long process. The sovereign should pass many hours with his or her bird of prey. Ideally, they should sleep in the same room so that the interaction and substitution between the two can be reinforced..$^{32}$ A ruler has to empathically understand the needs of his falcon similarly to the way he understands the needs of his subjects. Falconry can also prove the prince's maturity and leadership abilities. That's why images of young rulers (mostly male but not exclusively) with their falcons were very common in the fifteenth-, sixteenth-, and seventeenth-century portraiture.

The tradition of the ruler as a falconer is continued today in the Emirates, as already demonstrated

This is the reason why, throughout his book, Sheikh Zayed mentions the Arab origins of falconry as an almost perpetual practice in the Gulf region. Yannis Hadjinicolaou, "Macht wie die des Königs. Zur politischen Ikonographie der Falknerei" [Power like the king's. On the political iconography of falconry], in Hunting without Weapons. On the Pursuit of Images, ed. Maurice Saß (Berlin: De Gruyter, 2017), 87-106. Aristocratic women also practiced falconry during the time. 


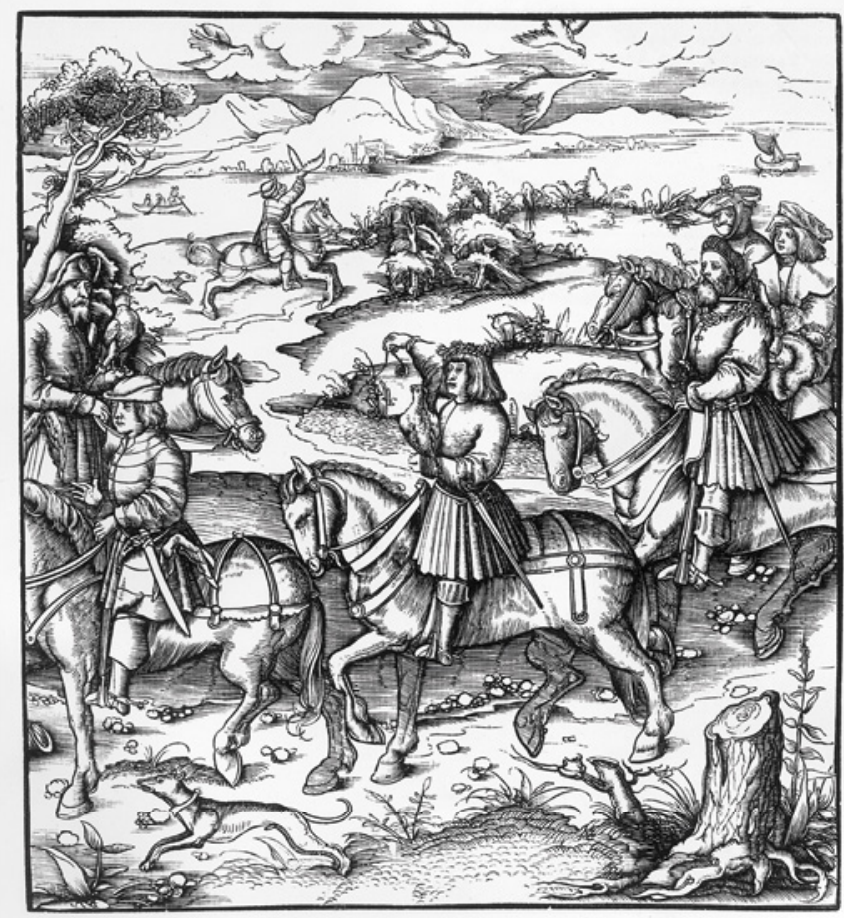

FIGURE 7.12

Hans Burgmair, Maximilian I on His Falconry Expedition. Woodcut, 1515 . by Zayed's image. Schools for falconry, such as the Emirates Falconers' Club, target a broad audience and convey the educational value of handling birds of prey. Besides the state advertising this practice by imprinting the image of the falcon on stamps, many illustrated books promote it among the youth. ${ }^{33}$ Thus, an identification with this heritage and way of life is crafted early on. This kind of habitus is a deeply visual one. Such pictures create "images" of young falconers who, at least iconically, continue the practice of their forefathers. This pictorial staging is of paramount importance because it is currently more visible in an Emirati's everyday life than the practice of falconry itself. Indeed, this practice has become more and more exclusive since hunting is strictly limited to very few protected regions in the U.A.E. ${ }^{34}$

Another vital source for such images is the film industry. Frédéric Mitterrand's documentary,

33 See, for instance, Randa Hamwi Duwaji's very popular, Hamad. The Young Falconer (Abu Dhabi: Erwda, 2000).

34 This is the reason why Emirati falconers go hunting mostly in Pakistan, Morocco, or Azerbaijan, among other places.
Cheikh Zayed, une légende arabe (Sheikh Zayed, an Arab Legend) (France, 2014), for instance, deals with the history of the U.A.E. and its founding father, Sheikh Zayed. ${ }^{35}$ In one scene, the viewers can see a classroom in an Emirati school in the early 1970s. The teacher carries a falcon on his fist and asks the children what kind of animal he is holding. The children answer all together "a falcon" and the teacher explains, "This is the national bird of the United Arab Emirates." ${ }^{\text {36 }}$ The school functions here as an ideological state apparatus, being the medium whereby the founding power of the nation is identified with the material symbol of the falcon. ${ }^{37}$

35 Frédéric Mitterrand, Cheikh Zayed, une légende arabe. France, 2014. YouTubevideo, 1:15. Posted September 2015. https://www.youtube.com/watch?v=opVjVpr2Rdo.

36 The fifteen-second scene I refer to here is to be found between 1.01.15 and 1.01.30. There are also many scenes with armed Bedouins inside and outside the court in Abu Dhabi who dance together, carrying falcons on their fists.

37 I use here Louis Althusser's term, as defined in Ideologie und ideologische Staatsapparate. Aufsätze zur marxistischen Theorie [Ideology and ideological state 


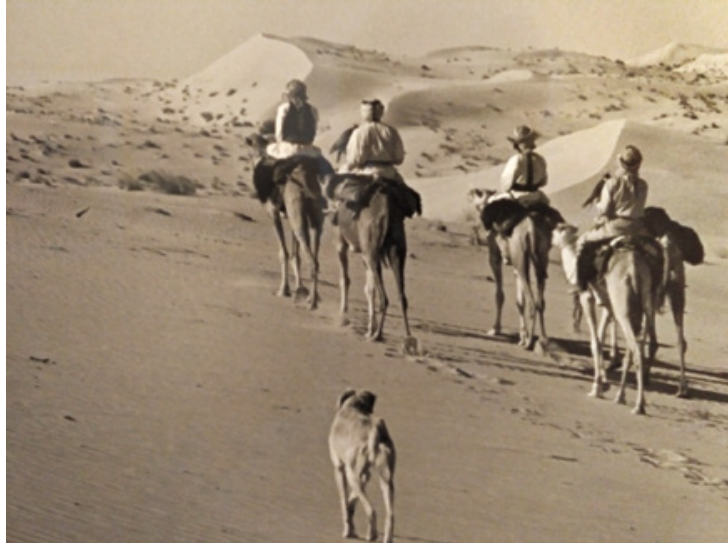

FIGURE 7.13

Cover image, Wilfred Thesiger, Arabian

Sands, showing a group of Bedouins, two of them holding hooded falcons.

In Wilfred Thesiger's famous book, Arabian Sands (1959), readers can see photographs taken by the author that capture the modus vivendi of the Bedouins. ${ }^{38}$ Among their activities, the handling of falcons is repeatedly presented in various images. These are some of the first falconry images in the U.A.E. since no artifacts or things related to this practice (apart from certain falconry furniture) have survived, partly due to the hostile climate and nomadic life of the local communities. For this reason, these photographs are valuable visual testimonies beyond the actual practice of falconry, which has been transmitted from one generation to the next. For instance, one of these images shows five camels and four men riding them, two of them holding hooded falcons. Accompanied by a dog, the Bedouins are moving toward sand dunes barely covered with vegetation to soon blend in the surrounding desert (fig. 7.13). The falcon is elevated to an iconic object, that in

apparatuses. Essays on Marxist theory], ed. Frieder Otto Wolf (Hamburg: vsA, 1977), 108-68.

Wilfred Thesiger, Arabian Sands (London: Longmans, 1959). This book has gone through several editions; the one printed by Motivate Publishing in Dubai contains several of Thesiger's images. Besides Al Jahili Fort in Al Ain, which has a section dedicated to Thesiger (alias Mubarak bin London), many other museums in the U.A.E. show Thesiger's photographs to illuminate the country's recent history. its intangible heritage is handed down to the next generation of (primarily male) Bedouins. It is a nomadic object, a weapon, a means for survival, and an ally in the desert. ${ }^{39}$ This memory in movement crafted and still crafts, to a certain degree, identities in the Arabian Gulf and beyond.

Birds of prey, camels, dogs, and weapons have been fixed features of Bedouin iconography throughout the centuries. It is through the Western eye (in this case Thesiger's) that a certain way of life is captured through the medium of photography, which creates an iconic identity of the Arabian Peninsula in general, and of the U.A.E. in particular. These images are elevated and aestheticized for a non-Arabic audience and are widely acknowledged as genuinely Bedouin and Arabic. And not only that: these images have gradually become historical testimonies for the locals. Thus, Thesiger's photographs have made a non-verbal contribution to a century-long tradition that was never made visible in photographic form before his book. Such photographs are not only reminders of previous times and of a way of life that has practically vanished nowadays, but in themselves, in their aesthetic construction, they are iconic creators of a Bedouin-Arabic identity. In other words, they are highly sophisticated ways of constructing historical memory and, henceforth, reality.

\section{Aby Warburg and the Notion of "Image Vehicle"}

The art historian or, rather, "image" historian (as he preferred to call himself) Aby Warburg coined the notion of "image vehicle" (Bilderfahrzeug), which he conceived not only as a mobile object (in this case, the falcon itself or images of falconry) but also as a motif and symbol that brings new associations and meanings to the object and may either overcome or conserve certain ways of

39 Christine Göttler and Mia Mochizuki, eds., The Nomadic Object: The Challenge of World for Early Modern Religious Art (Leiden: Brill, 2017). 
perceiving it. ${ }^{40}$ Falconry images are "image vehicles" in both a literal and a metaphorical sense. For Warburg, the European afterlife of pagan antiquity and philosophy and the Mesopotamian and Arab adoption of these values were of crucial importance because they enabled him to trace back the Western origins of a motif that had either been lost in time or transmitted and disguised in objects from these areas. Falconry belongs to this latter category, and its afterlife is reflected in and through images that do not simply illustrate this practice but construct it in a certain way. Images of falconry produce visual associations and, through them, ideas: we think through them and even act and interact with them. ${ }^{41}$

In his seminal lecture, "Italian Art and International Astrology in the Palazzo Schifanoia," considered today as having laid the foundations of iconology, Warburg maintained that "symbols for the fixed stars ... over the centuries, in their wanderings through Asia Minor, Egypt, Mesopotamia, Arabia and Spain ... have lost their Grecian clarity

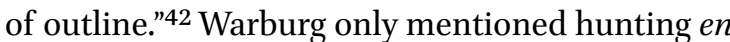
passant, although the image he is referring to in this lecture clearly shows a falconry scene which can serve as the perfect example of a migrating image and its afterlife. The fresco shows "the worldly activities of the court of Duke Borso, who

40 Aby Warburg, "Mnemosyne Einleitung (1929)" [Mnemosyne introduction (1929)], in Aby Warburg, Werke in einem Band [Works in a volume], ed. Martin Treml, Sigrid Weigel, and Perdita Ladwig (Berlin: Suhrkamp, 2010), 636-37.

41 Regarding the agency of an image, see David Freedberg, The Power of Images. Studies in the History and Theory of Response (Chicago: Chicago University Press, 1989); Horst Bredekamp, Image Acts. A Systematic Approach to Visual Agency (Berlin: De Gruyter, 2018); and Carolin van Eck, Art, Agency and Living Presence: From the Animated Image to the Excessive Object (Berlin: De Gruyter, 2015).

Aby Warburg, "Italian Art and International Astrology in the Palazzo Schifanoia, Ferrara," in Aby Warburg, The Renewal of Pagan Antiquity. Contributions to the Cultural History of the European Renaissance, trans. David Britt (Los Angeles: Getty Center for the History of Art and the Humanities, 1999), 565 . can be seen attending to official business or cheerfully riding out to hunt."43 In this image, different modes are brought together that may be described as "movement" and "stillness," and "the tamed" and "the untamed" and are all part of the dialectic of handling falcons (fig. 7.14). One can see, on the one hand, the hunting party with the hooded, calm falcons and, on the other hand, the restless horse rider whose falcon almost flies away from his fist. To describe both the inner and outer movement suggested by the image, Warburg coined the term "pathos formula" (Pathosformel) ${ }^{44}$

As shown in this image, falconry, hunting, and state business are interlinked, which reminds viewers of the similar images of Zayed and Frederick II. Considering falconry within a European courtly context, it is clear why its transformation from a non-Western practice to an Occidental image remained for Warburg invisible, a kind of blind spot: because a Western style of falconry derived from the Greek antiquity did not exist. The afterlife of European antiquity was, however, at the center of Warburg's interests. Indeed, Warburg mentioned the Mesopotamian and Arabian knowledge, especially in relation to astrological images. His fixation on European antiquity in relation to the image of the falcon and its afterlife is well-known. ${ }^{45}$ He gives the falcon a symbolic force, or dynamis, that is closely related to the images representing it and their materiality, especially when the bird of prey becomes an image itself. It is the floating of the bird and the intrinsic force of the animal in its co-productive relation to humans that are at the core of its dynamis. The falcon as actor and as material symbol is a model for a critical material

\footnotetext{
43 Ibid.

44 Marcus Andrew Hurttig, ed. Die entfesselte Antike. Aby Warburg und die Geburt der Pathosformel [The unleashed antiquity. Aby Warburg and the birth of the pathos formula] (Cologne: Verlag der Buchhandlung König, 2012).

45 See, for instance, Warburg's unfinished Mnemosyne Image Atlas, a project interrupted by his death in 1929. To fill out this gap, on the one hand, and to pursue the Warburgian tradition, on the other, I currently work on a book project titled The Political Iconology of Falconry.
} 


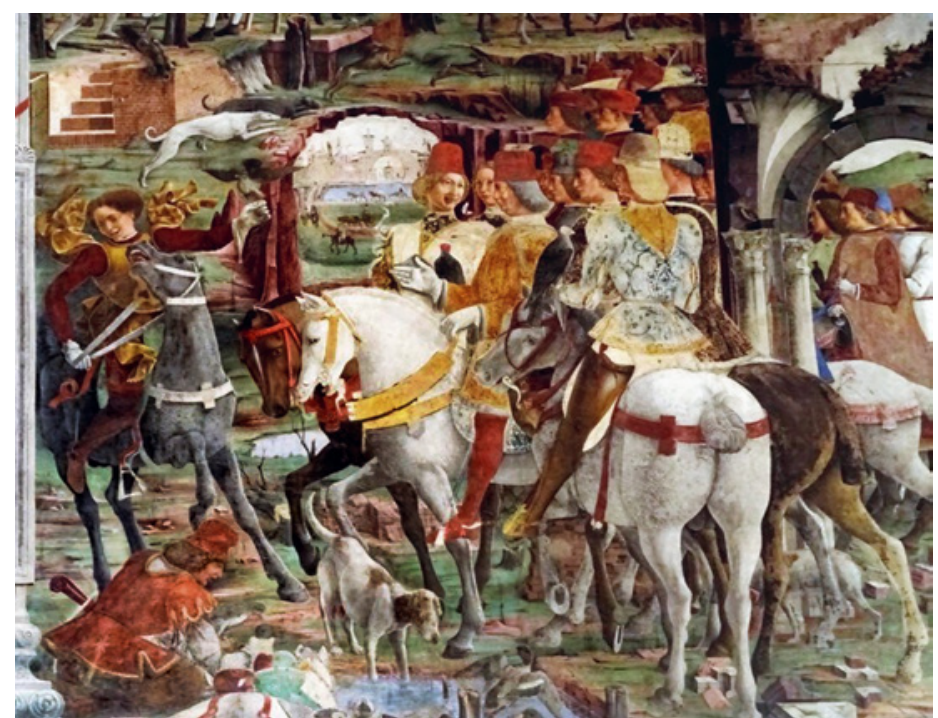

FIGURE 7.14

Francesco del Cossa, detail image of Allegory of April, ca. 1468. Fresco.

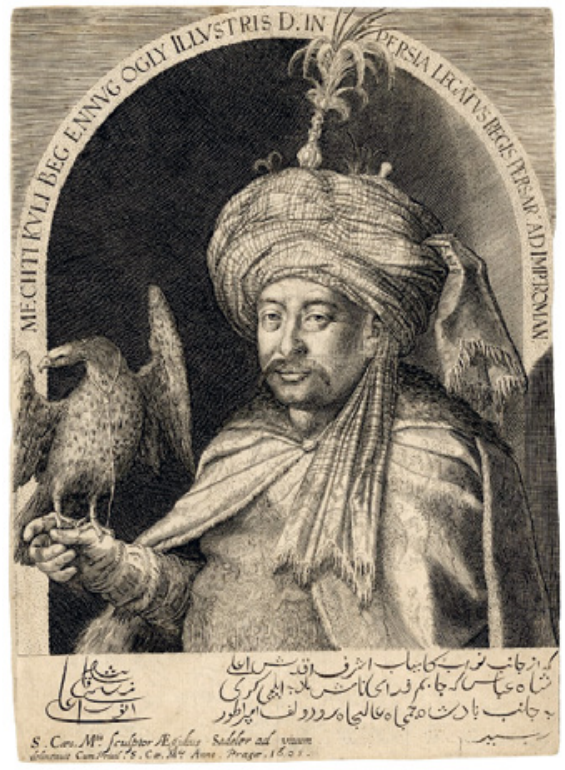

FIgURE 7.15 Aegidius Sadeler, Portrait of Mechti Kuli Beg, 1605. Etching.

iconology that understands basis (i.e., matter) and superstructure (i.e., symbol) as the horizontal field of a bestial activity, or ergon. Thus, Warburg spoke of animals as kinetic symbols, ${ }^{46}$ a view which finds a felicitous expression in the figure of the falcon as both an image vehicle and a nomadic object.

\section{The Falcon as Kinetic Symbol}

The transfer of functions, motives, and meanings, the (physical) movement of crafted objects, the falcons themselves (as diplomatic gifts), ${ }^{47}$ and the instruments of falconry (such as the hood or the lure) were used in the past to connect and still connect today countries and civilizations. A print from 1605 by Egidius Sadeler with inscriptions in Persian and Latin shows the Persian ambassador Mechti Kuli Beg ad vivum at the court of Rudolf II, in Prague, carrying a falcon (fig. 7.15). The bird of prey is not only a symbol of the Orient but also a means for strengthening diplomatic relations. This speaks not only for the movable medium of images printed on paper but also for the content depicted by such images, which was meant for an international audience, not only a Persian or a Bohemian one. Thus, the interactions among Prague,

\footnotetext{
47 See Marcel Mauss, The Gift: The Form and Reason for Exchange in Archaic Societies (New York: W.W. Norton, 1990).
} 


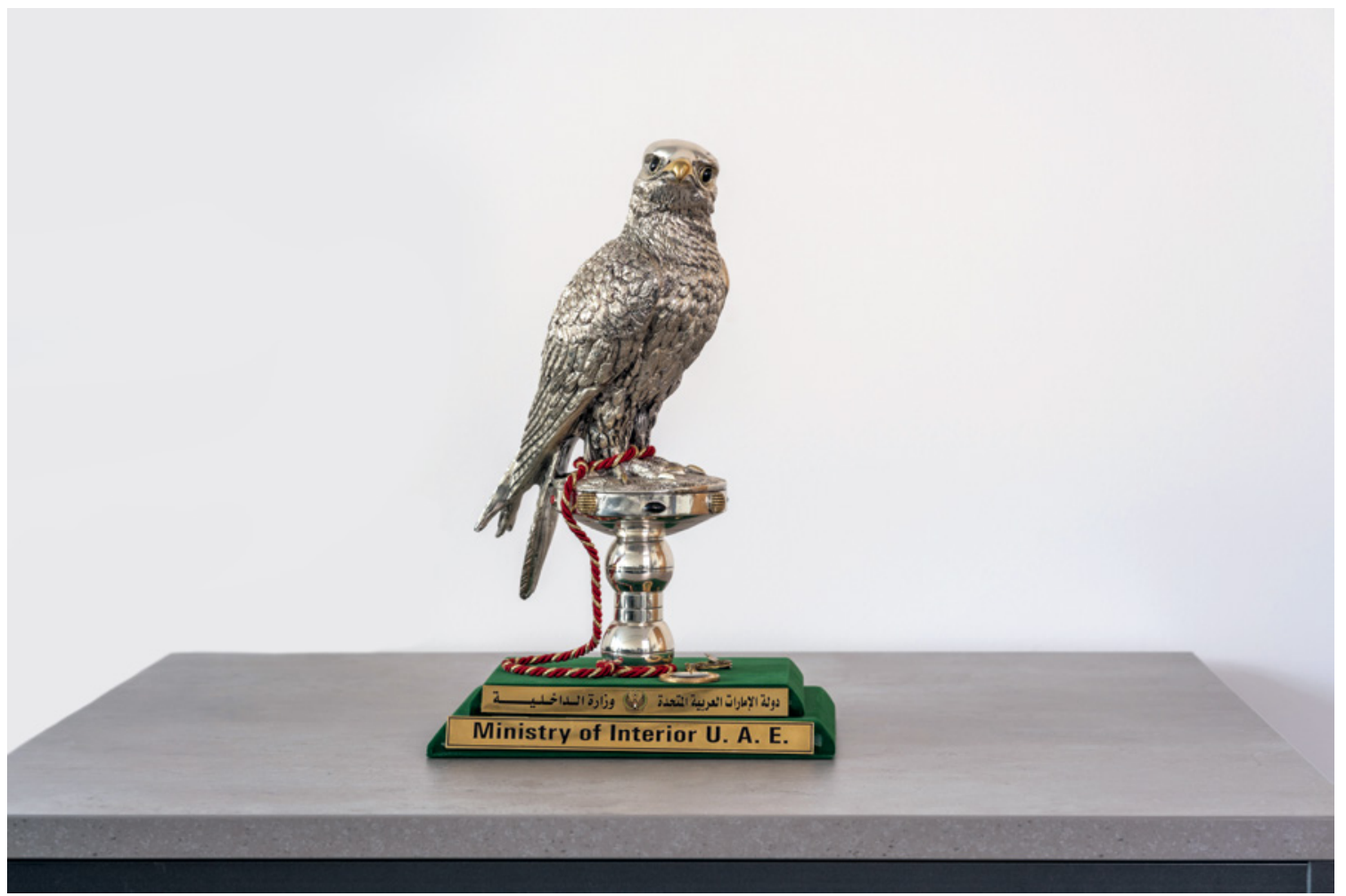

FIGURE 7.16 Falcon statue. Gift to the German Interior Minister from his U.A.E. counterpart, 2010.

Persia, and other civilizations are underlined and reinforced through this falcon iconography. ${ }^{48}$

48 Keelan Overton, "Ambassadors and Their Gifts," in Gifts of the Sultan. The Arts of Giving at the Islamic Courts, ed. Linda Komaroff (New Haven, CT: Yale University Press, 2012), 140; Rudolph Matthee, "Die Beziehungen des Iran zu Europa in der Safawidenzeit: Diplomaten, Missionare, Kaufleute, und Reisen" [Iran's relations with Europe in the Safavid era: Diplomats, missionaries, merchants, and travel], in Sehnsucht Persien. Austausch und Rezeption in der Kunst Persiens und Europas im 17. Jahrhundert \& Gegenwartskunst aus Teheran [Yearning Persia. Exchange and reception in the art of Persia and Europe in the seventeenth century \& contemporary art from Tehran], ed. A. Langer (Zurich: Scheidegger \& Spiess, 2013), 26; Gary Schwartz, "Terms of Reception. Europeans and Persians and Each Other's Art," in Mediating Netherlandish Art and Material Culture in Asia, ed. Thomas da Costa Kaufmann and Michael North (Amsterdam: Amsterdam University Press, 2014), 46; Lydia R. Dorn, Diplomatenporträts der Frühen Neuzeit. Botschafter und Gesandte in der Malerei von Tizian über Van Dyck bis Aved [Diplomatic portraits
The continuous movement of falcons as gifts occurred through diplomatic missions and gift exchanges that often included and still include live falcons or images of falconry. A 2010 gift from the U.A.E. Interior Minister, Saif bin Zayidal Nuhayyan, to his German counterpart, Thomas de Maizière, identifies the falcon as the symbol of the United Arab Emirates (fig. 7.16). Since the foundation of the U.A.E. in 1971, the falcon has been used as a symbol of unity by the Bedouin tribes while also alluding to the tribal structure of the local society. In other words, the protection of the interior is represented in the exterior through the apotropaic falcon.

Similarly, the work of contemporary artist Raja'a Khalid from Dubai (born 1984) brings together the global and the local through performances such as Palace Gossip (2018), which

of the early modern period. Ambassadors and diplomats in paintings from Titian to Van Dyck to Aved] (Berlin: Deutscher Kunstverlag, 2017), 187. 


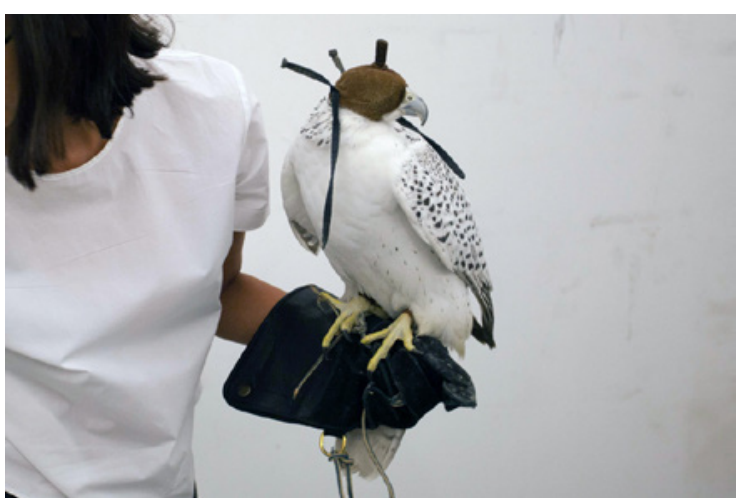

FIGURE 7.17 Palace Gossip. Performance reading by Raja'a Khalid, 2018.

employs falconry as a unifying symbol. ${ }^{49}$ The dialectical relation between local traditions and an international audience is not only one of harmonious togetherness, though. Khalid's work contains pictures from the famous Abu Dhabi Falcon Hospital (its lesser known mews, which houses birds of prey), where every year thousands of falcons from around the region and beyond are cared for, as well as photographs of a woman falconer reading indoors during the aforementioned performance (fig. 7.17). She is wearing an inconspicuous, white T-shirt, allowing the viewers to focus their attention on the hooded gyrfalcon on her fist. The image sheds light on the major role of the falcon in the region, which is embedded in the multicultural context of today's Emirati society. Significantly, her work also points to the growing interest of local Emirati women in falconry. More and more women participate in falconry workshops in the U.A.E., an engagement which originated in Medieval Europe and, later, in Moghul

49 Something similar, with different references, does the Bahraini artist Ghada Khunji who, in her self-portraits, follows Cindy Sherman's and Frida Khalo's tradition. For details, see her photo series faRIDA.
India, where Muslim aristocratic women were an integral part of falconry imagery. ${ }^{50}$

Falconry migrated to Europe from the Arab world and went through various visual transformations through printing, painting, and, more recently, new media, such as photography, film, or the Internet. This renewed interest in falconry has unleashed its iconic afterlife in the Arabian Peninsula. While the Western media has attempted to shed light on this Arab theme, it has often created a productive conflict between form and content in a unified world that acknowledges local traditions, as the example of Sheikh Zayed has shown. However, the point of departure of the falcon iconography is not the Greek antiquity; rather, it is a multilocal one. As Warburg used to say, "Athens wants again and again to be recaptured from Alexandria." 51 Today, we should add, "Not only from Alexandria but also from Arabia."

A falcon is a bird of prey and a cultural symbol with a huge visual impact, iconic agency, and kinetic power in the U.A.E. It is, in itself, a locus of vivid memories, a means of survival in a hostile environment, and a symbol that has allowed the Emiratis to preserve their identity in a place where history and culture are constructed in totally different ways than in the Western world. In their constant movement and transformation, falcon and falconry are ideal ways of thinking of the U.A.E.'s past in its dynamic continuity with the present, a continuity that is greatly reliant on local images that act as forms of kinetic and symbolic capital.

50 See Sami Ur Rahman, The Art of Falconry in the Mughal Empire (Abu Dhabi: Rainbow Graphic, 2017), 104.

$5^{1}$ I use here Christopher D. Johnson's translation of "Athen will eben immer wieder neu aus Alexandrien zurückerobert sein," in Memory, Metaphor, and Aby Warburg's Atlas of Images (New York: Cornell University Press, 2012), 119. 